\title{
ANALYSING THE URBAN ENVIRONMENT SUSTAINABILITY INFLUENCED BY TOURISM IN IRAN (DISTRICT 1 OF TEHRAN METROPOLIS)
}

\author{
Zohreh FANNI* \\ Department of Geography and Urban Planning, \\ University of Shahid Beheshti, Tehran, Iran, e-mail: z-fanni@sbu.ac.ir \\ Syed Mohammad REZAZADEH \\ Department of Geography and Urban Planning, \\ University of Shahid Beheshti, Tehran, Iran, e-mail: M_rezazadeh@sbu.ac.ir
}

\begin{abstract}
Citation: Fanni, Z., \& Rezazadeh S.M. (2018). ANALYSING THE URBAN ENVIRONMENT SUSTAINABILITY INFLUENCED BY TOURISM IN IRAN (DISTRICT 1 OF TEHRAN METROPOLIS). GeoJournal of Tourism and Geosites, 23(3), 719-730. https://doi.org/10.30892/gtg.23308-322
\end{abstract}

\begin{abstract}
Considering the goals and dimensions of development and the characteristics of different communities, sustainability should be pursued such as community-based development based on the strategic principles of the urban environment influenced by tourism with respect to the citizen's participation. Therefore, to meet these growing needs, the necessity of appropriate spaces and places in the urban environment for tourism is well identified and planned, and then the urban environment is screened through the necessary strategies, integrated local-level monitoring and management for the metropolis of Tehran. The purpose of this research is to analyze the status of quo and desirable development in the future of Tehran metropolitan in the field of altered environment through tourism activities. The methodology was developed within the framework of sustainable urban development influenced by tourism paradigms and by urban tourism perspectives. For this purpose, the data collection was conducted using the library, survey, and interviews with experts and authorities in the study area. The results showed that some indicators such as enjoyment of natural areas (83.13\%), recreation and leisure activities (79.36\%), observation of nature's exciting landscapes (72.71\%), escape from daily stress $(72.18 \%)$, gathering together, visiting and traveling with friends and relatives (67.72\%), visiting natural areas and intact (67.62\%), and urban stress relief $(60 \%)$ had the most motivations for tourists to Tehran urban environment sustainability. Also, the results indicate that the amount of tourists Visit from the natural areas is equal to $56.96 \%$, protection of plant species, $54.38 \%$, protection of animal species and in the bird's parameter is $86 / 42 \%$.
\end{abstract}

Key words: Urban Environment, Tourism, Sustainable City, Tehran

\footnotetext{
* Corresponding author
} 


\section{INTRODUCTION}

In the era of globalization and rapid communication, planning for a healthy and safe environment is a prerequisite condition for the cities sustainability and for the whole urban community. The environmental debate during the 1990 s was on the international agenda, especially related to major international meetings and summits as the Earth Rio Summit (UNCED, 1992). World Education Forum in Dakar 2000, World Summit on Sustainable Development in Johannesburg, 2002, United Nations Decade of Education for Sustainable Development in 2005-2015. Global institutions, national governments, and local communities are also increasingly concerned on the environment future embracing the concept of "sustainable development" (Redclift, 2008). One classic case in point is the aforementioned 1973 ecological planning project for the new town of The Woodlands in Texas, the United States, by Ian McHarg and his colleagues from Wallace, McHarg, Roberts and Todd (WMRT) - the Philadelphia based architecture, landscape architecture and urban planning firm that were contracted for the project (Yang \& Li, 2016). The changes that cities occur in land use caused discrepancies in Albedo, and this has important implications for the energy cost of a region (Jalalian \& Pejouyan, 2009). In this way, the lungs of the ground are wrinkled and degraded, as well as lands that have been lost due to deforestation and excessive vegetation cover (for example, in parts of the coast), to the planted land, Albedo are higher (Faghfur, 2009). The mental and physical health of population are directly related to the quality of "diverse environments", that their elements from the household to the workplace are interacting on the international scale. On the other hand, the main problem is largely based on this fact that human progress in most cases affects the urban environment (Mies \& Shiva, 2005). On the World Bank's agenda, the World Bank tries to prioritize a set of environmental problems in the cities of developing countries (World Bank, 2007). However, to reduce the people vulnerability to environmental hazards associated with urban tourism, they emphasize the support of local and national governments to curb the growth and strengthening of environmental sustainability laws and strategies (Leitman, 2010). Since, the Brent land Commission "Our Common Future" report in 1987, major discussions have focused on the sustainability of fundamental differences was published in the ideas of development, economic growth, social change and urban environmental issues (Rees, 2010, Lohamman, 2008). In recent years, there has been a widespread concern on the environment and its protection a global challenge. Hence, the extent and the diversity of urban environmental issues and their interchangeable interactions have made the need for urban environmental considerations more difficult (Abe et al., 2000; Rojeck \& Urry, 2008).

\section{LITERATURE REVIEW AND THEORETICAL BACKGROUND}

The analysis of the concept of nature and man: The philosophy of Hegel's, nature unveils that; nature is a reasonable and logical consequence of the rational cause. Nature is the same intellect that have outsized the natural form (Foroughi, 1998). From Hegel's perspective, the man with intellect is the most complete biological species, and the only being possessed the soul or soul, which distinguishes him from a purely physical nature. In the Marx's view, humans, through their ordinary changes the environment, bring it to their service and dominate it. Marx paid a great attention to the problem of the need for the basis of the dialectical fuel and physical relations of man and nature. From Huberman's point of view, our only relationship with nature is the instrumental relationship that governs our productive and computational interests about how we can better utilize nature to meet our needs (Poulantzas, 1975). The environment consists of nature, human societies as well as human-made spaces, and the entire biological environment of the planet, the biosphere, is taught (Soltani, 2008). The environment refers to the environment and the place of our life and clearly includes humans and nature (Anderson, 2009:1). The notion of 
human beings' enlightened self-interest is concerned with two fundamental questions in ecological practice-what should a "harmonious human condition" look like on the earth? How should it be pursued? In the belief that there exists a relationship of human-nature reciprocity (Berkes, 2012: 286-287), it states plainly that it is in human beings' selfinterest-ethical, moral as well as material-to respect and appreciate the intrinsic value of all living and non-living beings on the earth (Berkes, 2012: 286-287; Cafaro, 2001:416). Leisure is a complex concept, considered both as mental and practical activity. Furthermore, leisure is synonymous with the free time of a person who can volunteer to perform activities such as recreation and circulation (Hall \& Jenkins, 2015). The urban dictionary dictates the definition of leisure as follows: Leisure time is said to be a moment when no one has any obligation or responsibility to do anything, and on this basis, it is time for hobby and pleasure to be free (http://encarta.msn.com/thesaurus_/leisure; Xiang, 2014: 65-66; Yang \& Li, 2016). As Hall (2002) mentioned, Dumasdir (2002) consider that leisure refers to three situations: firstly, it refers on, spending leisure time at times outside of work, education, and religion; in other words, leisure represents the free time of an individual. Secondly, leisure is a pleasure, and thirdly, leisure must be a provider of a rest, entertainment, and self-promotion of individuals. Recreation is a personal and collective activity that takes place in the pursuit of leisure and pursues goals such as enjoyment and pleasure from leisure time (Hall, 2002). Tourism is also referred to person act that travels more than a day and resides in a place beyond his lifetime for less than a year to trade and other purposes (Smith, 1995).

Table 1. Dimensions of nature-centered tourism definition with Urban Environmental Behavioral Approach

\begin{tabular}{|c|c|c|c|c|}
\hline Authors & \multicolumn{4}{|c|}{ Dimensions } \\
\hline $\begin{array}{c}\text { Ingram et al., } \\
1987\end{array}$ & $\begin{array}{c}\text { Environmental } \\
\text { Behaviors }\end{array}$ & Subject & Tourism Goals & $\begin{array}{c}\text { Features of the nature- } \\
\text { centered tourism area }\end{array}$ \\
\hline $\begin{array}{c}\text { Wilson, } \\
1988\end{array}$ & $\begin{array}{c}\text { Sustainable consumption } \\
\text { of natural resources }\end{array}$ & Environment & $\begin{array}{c}\text { Sustainable use of } \\
\text { natural resources }\end{array}$ & $\begin{array}{c}\text { Natural areas and } \\
\text { activities in nature }\end{array}$ \\
\hline $\begin{array}{c}\text { Valentine, } \\
1992\end{array}$ & $\begin{array}{c}\text { Protection and do not } \\
\text { encroach }\end{array}$ & Natural effects & recreation & $\begin{array}{c}\text { Nature, National Parks } \\
\text { and Biological Reserves }\end{array}$ \\
\hline $\begin{array}{c}\text { Lusar et al., } \\
1995\end{array}$ & $\begin{array}{c}\text { Maintaining natural } \\
\text { phenomena }\end{array}$ & Natural events & $\begin{array}{c}\text { Earn experience, } \\
\text { watch and enjoy }\end{array}$ & Natural intact areas \\
\hline $\begin{array}{c}\text { Goodwin, } \\
1996\end{array}$ & $\begin{array}{c}\text { Maintaining species and } \\
\text { respecting local culture }\end{array}$ & $\begin{array}{c}\text { Environment } \\
\text { \& Culture }\end{array}$ & $\begin{array}{c}\text { Appreciation, research } \\
\text { and enjoyment }\end{array}$ & Intact areas \\
\hline $\begin{array}{c}\text { Bair, 1997 } \\
\text { cultural phenomena and } \\
\text { sustainability }\end{array}$ & $\begin{array}{c}\text { Environment } \\
\text { \& Culture }\end{array}$ & $\begin{array}{c}\text { Appreciate and } \\
\text { wise use of the } \\
\text { environment }\end{array}$ & Areas and resources \\
\hline $\begin{array}{c}\text { Newom et al., } \\
2002\end{array}$ & $\begin{array}{c}\text { Preserve natural } \\
\text { phenomena }\end{array}$ & Environment & $\begin{array}{c}\text { Education and } \\
\text { enjoyment }\end{array}$ & Natural regions \\
\hline $\begin{array}{c}\text { Nature Tourism } \\
\text { Center, South } \\
\text { Carolina, 2002 }\end{array}$ & Natural Protecting & Environment & $\begin{array}{c}\text { Watch and } \\
\text { recreation }\end{array}$ & Natural regions \\
\hline $\begin{array}{c}\text { Durin Society, } \\
2002\end{array}$ & $\begin{array}{c}\text { Protectionand } \\
\text { dimensions of } \\
\text { sustainability }\end{array}$ & Environment & $\begin{array}{c}\text { Appreciation, } \\
\text { research and } \\
\text { enjoyment }\end{array}$ & $\begin{array}{c}\text { Environment \& } \\
\text { Sustainable Economic } \\
\text { Activities }\end{array}$ \\
\hline $\begin{array}{c}\text { Ingram et al., } \\
1987\end{array}$ & Non-profit activities & Natural events & watch and enjoy & $\begin{array}{c}\text { land Phenomena, } \\
\text { animals, plants and air }\end{array}$ \\
\hline
\end{tabular}

A visitor traveling's to a place other than his own place of residence for less than 12 months and whose purpose is not to make money in the destination. A passenger is also one who travels between two or more places (World Tourism Organization, 1995). The 
three major dimensions of nature-centered tourism are: experience (the style of a different trade of nature, the level of interaction, the social context, and duration of stay), style (different styles in payments and the length of time of tourism) and location (change of location in relation to access and degree of remoteness, development of partnership, ownership and elegance) (Hall \& Jenkins, 2015). Ecological practice must therefore attend simultaneously the vast variety of intertwining social -economic relationships within the human and the nature. Yet, all of these relationships are characterized by high levels of complexity, wickedness, and in particular, context dependency (Xiang, 2013: 1-2; 2014: 66). This unique characteristic differentiates ecological practice from other social practices to ecological practice and potential advantages it can bring. The first commentary written by Steiner (2016) starts with Ian McHarg's design with nature theory presented in the essay by Yang and Li (2016) and comments on the later development of landscape ecology, urban ecology, and ecosystem services. One thing we can learn from the history is that those ecology-based theories have the potential of supporting ecological practice; to realize this potential to its fullest extent, however we must seek the guidance of wisdom, ecological wisdom. The second commentary by Liao and Chan (2016) builds upon the papers in this special issue, especially that by Xiang (2016) and calls for further research to answer two questions, "What is ecological wisdom?" and "How does ecological wisdom relate to ecological knowledge?" Although we may find manifestation of ecological wisdom in various projects, few have consciously paid attention to and intentionally sought for ecological wisdom in practice. In order to make ecological wisdom a more inspiring power that is informative and relevant to current and future generations these two questions need to be further studied and widely shared in the academic dialogues.

\section{Sustainability of Urban Environment Affected by Tourism}

Generally, the local wisdom emerges through the internal process and passed for a long time as a result of the interaction between humans and their environment. This long process of evolution would lead to the emergence of values system that crystallized in the form of common law, belief and local culture. Thereby, substantially local wisdom is the norm practiced in a society which is faithfully believed and become a reference in their daily life. Therefore, it is reasonable if Geertz (1973) says that local knowledge is an entity that is crucial for human dignity in the community (Ernawi, 2009). Participatory approach or community based development is one of strategies that can bridge the development interests which emphasize in paradigm of economic based with sustainable development (socio - ecological based) (Wikantiyoso, 2009). The indirect impact of tourism is much broader in its socio-economic nature. The reason for this is the effect of the multiplier, when the chain of "expenses - incomes" through tourism stimulates the development of economy and other related industries associated with it. If more tourists spend money at the place of the stay; the greater the amount of transaction "costs - income than the higher the indirect (multiplicative) impact of tourism (Ruslan, 2018). In geography, the concept of environment refers to all the local or regional features. In other words, the set of elements that cover the point of the phenomenon occurrence and the surrounding environment (Badrifar, 2015). In other word, nature tourism is considered as one of the best tourism destinations for sustainable development (Bomanian \& Mahmoudineghad, 2016). Also, tourism is the desire to use space in leisure with different motives includinge a flow of capital and humanity, culture and interaction between them, which has different effects in the geographic context and therefore, in spatial processing patterns each of them has a specific spatial structure and function (Fanni \& Rezazadeh, 2015). The growth of environmental tourism suggests that organizations and natural resource conservation groups have become more active in matters such as monitoring, promoting and even pursuing tourism activities with an emphasis on environmental protection, especially in 
developing countries (Hall \& Jenkins, 2015). Considering the environment and preserving, it is a culture as well as awareness of the human personality as a thinking being and his awareness (Tume, 2015). Therefore, environmental care is a necessary part of a cultural policy and a balance between the enjoyment of visitors and the protection of natural attractions (Iran Earth, 2016). In the literature of tourism, the environment (natural and artificial) is not only a main context for tourism, but also is an attraction in which create interactions between the environment and tourism activity (Bamanian and Mahmudineghad, 2016). Therefore, sustainable tourism meets the needs of tourists of the present and host societies, while expanding opportunities for the future and using resources in a way that simultaneously preserves cultural values, ecological processes, Biodiversity, and life support systems are responding to the economic, social and aesthetic needs (Gee, 2000). Hence, planning for sustainable urban tourism also includes three levels of market, urban growth and local communities (Faraji Rad \& Nasiri, 2010). The form of community participation can also be seen from their initiative in designing and developing the tourist areas. Communities also conduct land management in mutual aid such as: strengthening the terracing with stone, planting grass, and fodder bank; division and arrangement of land boundary that become part of the group; as well as constructing inspection track some of which have been developed attraction tracks (Taufiqurrohman, 2014). Some of the principles of sustainable development and its relevance to the environment affected by tourism in accordance with the Earth Summit Conference in Rio de Janeiro, Brazil in 1992 include:

1. Understanding the environment value and the focus of human being in the focus of sustainable development goals.

2- Considering the longer horizons in planning.

3. Cooperation to eradicate poverty as a prerequisite for sustainable development.

4- Participation of citizens at appropriate levels and their participation in the decision-making process.

5. Considering the role of women in the field of environmental management and development and the need for their participation in sustainable development.

6. Supporting the identity of the culture and resources of indigenous people and local communities due to their traditional customs practices in environmental management and development (Movahed, 2017).

Rasehki (et al. 2015), in their research entitled "The Effect of Environmental Tourism: A Case Study for Selected Developing and Developed Countries", payed to the role of tourism industry as one of the most important factors in increasing global economic activity. The authors point to the scope of the tourism industry more than employment creation and its economic effects, and along with this, environmental issues of tourism have been always their concern. The critique of research results shows that the impact of tourism on the environment of developed countries is positive, while this effect is negative in developing countries. Distinction: A compilation study of the present study on the subject of urban environmental assessment and regional and neighborhood tourism in Iran.

Anna (et al. 2017), in a study entitled "Indigenous People and Tourism: Challenges and Opportunities for Sustainable Tourism", addressed a series of issues related to sustainable indigenous tourism. Researchers have argued that the capacity of indigenous tourism as an effective and prominent instrument for sustainable development has discussed the details of the realities of urban and native tourism for development. However, the critique implies that, despite the presentation of services provided to tourists, the main factors that attract tourists are not emphasized in the mainstream of native tourism and management, and these factors (tourism opportunities and strengths) are not as the characteristics of the tourist's travel, but also as the main drivers of tourism. 
Florian (et al., 2015), in a study entitled "Sustainable Urban Quality in the Emerging City of Doha," examined the quality of urban sustainability in Doha. After introducing the basic framework as a model, the three dimensions Sustainabilityenvironmental productivity, economic growth and social justice-have been analyzed in relation to the urban quality required for their production. As a result, researchers, in general, have emphasized the challenges posed by the creation of sustainable urban development mechanisms in Doha. In this research, although the triple environmental sustainability model has been used, the analysis has not been studied quantitatively.

Summiting it all after the Rio Conference in 1992, it turned out that the optimal alignment of heterogeneous goals of sustainable tourism (economic profits, preserving the social integrity of local communities, the affirmation of cultural identity of the receptive areas, environmental protection and satisfaction of tourists) is in reality like the attempt to square the circle. Due to problems of implementation of the concept of sustainable tourism, some authors (Fennel, 2009; Tribe, 2009) invite for another interpretation of this concept. Taking into account the fact that the objectives of a sustainable development can be equally difficult to implement, because of the conflicting interests of the participants in the tourist economy, the emphasis should be placed on the adoption of norms and principles, particularly the ethical, which would be respected by all stakeholders in tourism. The key challenge for planning sustainable tourism development, nevertheless, which never seems to emerge, is the limitation of the human perception of time. It is extremely difficult to keep a long-term time-horizon in mind in our day-to-day behavior, and in our short-term and even long-term decision-making (Lew, 2010). Development of urban tourism based on the preservation of the environment cannot be separated from the element of empowerment. Successful development can be measured through three main aspects i.e. economic aspects to measure its added value in the economy of the community, social aspects to measure the community as stakeholders in managing tourism urban, and environmental aspects to measure impacts of tourism in the perspective of environmental conservation (Nugroho, 2010). Therefore the adoption of tourism as a development strategy is commonly based on the benefits that tourism potentially brings to local people in destinations. One of the most frequently reported benefits of tourism is the generation of employment not only for those who live in the localities but also for those in surrounding areas or who temporarily immigrate in search of tourism income (J Carlos, 2013).

\section{Research goal and question}

This research aims at analyzing and improving the status quo and development of the future situation of District 1 of Tehran metropolitan in the context of the environment affected by urban tourism with respect to the sustainable urban development process and using the LYKERT collaborative spectrum to analyze the situation using points of strength, weakness, opportunity and threats in the region. Therefore, planning for a healthy safe environment for the sustainability and health of the city is a prerequisite for Tehran's metropolis development, and should be considered in every urban community. Therefore, the main question of this study is that the assessment of the urban environment affected by tourism, how can it contribute to sustainable urban development in the city of Tehran?

\section{STUDY AREA}

Tehran province is one of the 32 provinces of Iran, with a total area of $12981 \mathrm{~km}^{2}$. It is located in the north of the central plateau of Iran, spanning over $34^{\circ}$ to $36^{\circ} 5^{\prime} \mathrm{N}$ and $50^{\circ}$ to $53^{\circ} \mathrm{E}$ (Fig. 1). Its population is approximately $13,281,858$ million and the province is composed of ten cities. Tehran province is the richest province in Iran as well as it contributes approximately 29\% of the country's GDP (Gross Domestic Product). Furthermore, it houses approximately $18 \%$ of the country's population (Figure 1). It is the 
most industrialized province in Iran and $86.5 \%$ of its population resides in urban areas while the remaining $13.5 \%$ resides in rural areas. Tehran province has over 17,000 industrial units employing 390,000 people, $26 \%$ of all units in Iran.

The province contains 30\% of Iran's economy, and comprises 40\% of Iran's consumer market. The metropolis of Tehran is the capital city of the province and of Iran. Tehran, with a population of more than 7 million, is ranked amongst the 20 most populous metropolitan cities of the world already suffering from all the illnesses of large metropolises such as air, noise and scenery pollution and over- crowding (Tehran City Planning and Study Center, Detailed Planning Region 1, 2006). The area of Tehran's metropolis has many touritic attractions. The sustainable tourism strategy in a today's world is a comprehensive approach that seeking the long-term growth in the tourism industry without threatening the natural habitats. It emphasizes that in the tourism development, it will also be able to identify certain aspects of the environment in a positive direction (Papoli Yazdi, 2015) (Figure 2).

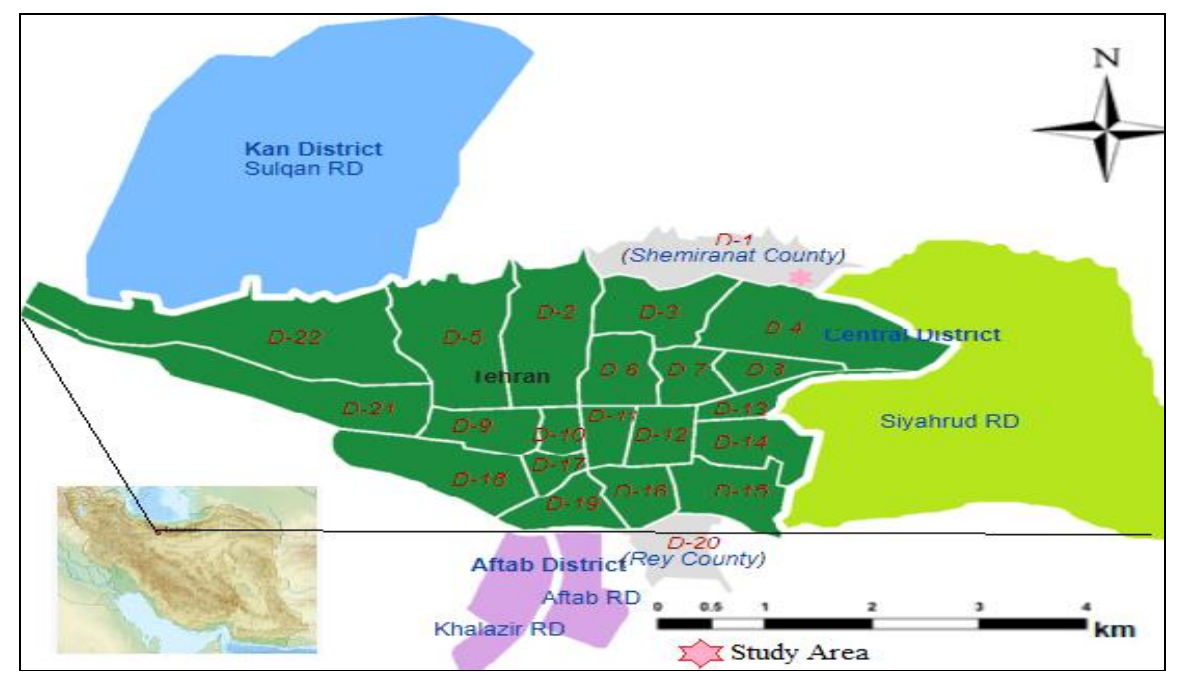

Figure 1. The study area

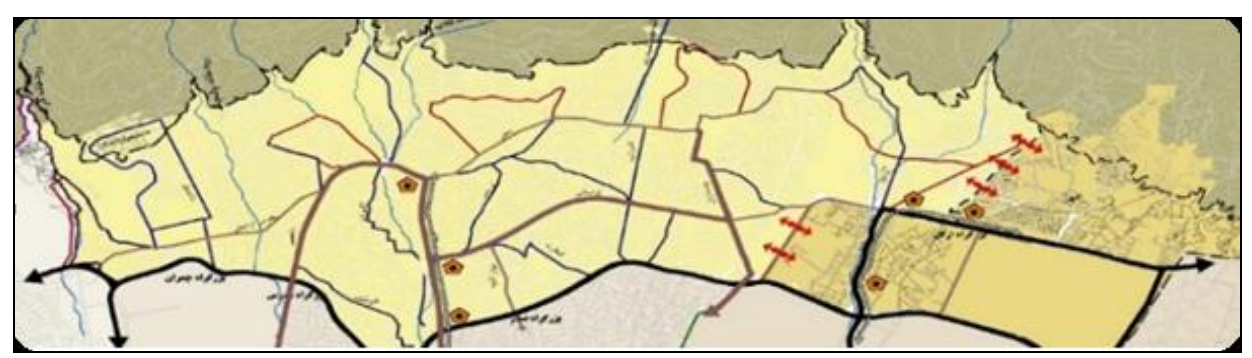

Figure 2. Sketch pattern of District 1 and its neighboring areas (Source: Tehran City Planning and Study Center, Detailed Planning Region 1, 2016)

\section{MATERIAL \& METHODS}

Basically, the samples of the present study consist all residents of two neighborhoods Velenjak and Darakeh in District 1 of Tehran metropolitan. In addition, we studied the characteristics and capacities of the urban environment of District 1 at the macro level and then historical, natural features, human inhabitants of neighborhoods of this district in Tehran metropolis in the micro level. The total statistical population of this 
District according to the latest results of the census of the Iranian Statistical Center in 2016 has been 439467 thousand (Statistics Center of Iran, results Census of 2016). The methodological background is designed to identify and to explore the capacities, and the potentials of the environment and urban tourism to plan and to develop the urban environment of exploration (due to the new aspect of the subject and the combination of both descriptive-analytical methods and field method) and in terms of content and nature, it is based on descriptive-analytical-developmental method. The methodology of research has been developed within the framework of sustainable urban development paradigm influenced by tourism. Research hypothesis is that considering the issues and environmental approaches influenced by urban tourism, the existence of an increasing partnership in reducing conflicts between visitors' activities and urban environmental health, from important analyzes and evaluations in the formation of integrated environmental management and promotion Sustainability of tourism and health of the urban community is within the boundaries of a metropolitan area of Tehran.

\section{FINDINGS AND RESULTS}

Shemiranat Region, (very close to both study neighborhoods), that is located in the north of Tehran province, politically is considered as a separate city, but in terms of its physical, cultural and socio-cultural dimensions, cannot be separated from Tehran. As a result, the physical conjunction of Tehran and Shemiranat has transformed these two cities into a single body that is strongly influenced by each other. Significant parts of the natural and human attractions of the province are also located in this area.

Table 2. Types of incentives for tourists to visit the District 1 (Particularly Darakeh and Velenjak) using the LYKERT model

\begin{tabular}{|l|c|c|c|c|c|c|}
\hline \multicolumn{1}{|c}{$\begin{array}{c}\text { Interest } \\
\text { Motivation }\end{array}$} & Velenjak & Darakeh & Velenjak & Darakeh & Velenjak & Darakeh \\
\cline { 2 - 7 } & V H & V L & L & M & H & V H \\
\hline Recreation and leisure & 81 & 196 & 81 & 196 & 81 & 196 \\
\hline $\begin{array}{l}\text { Meeting, meeting and traveling with } \\
\text { friends and acquaintances }\end{array}$ & 88 & 136 & 88 & 136 & 88 & 136 \\
\hline Enjoy natural areas & 101 & 209 & 101 & 209 & 101 & 209 \\
\hline Use of local food and drinks & 61 & 92 & 61 & 92 & 61 & 92 \\
\hline An opportunity to learn and grow consciousness & 71 & 80 & 71 & 80 & 71 & 80 \\
\hline Experience a new way of life & 82 & 75 & 82 & 75 & 82 & 75 \\
\hline Visit of ancient monuments & 72 & 82 & 72 & 82 & 72 & 82 \\
\hline Buy local souvenirs & 50 & 67 & 50 & 67 & 50 & 67 \\
\hline Buying and selling goods trade) & 36 & 65 & 36 & 65 & 36 & 65 \\
\hline Meet the artistic and cultural attractions & 54 & 51 & 54 & 51 & 54 & 51 \\
\hline Familiarity with the culture of local residents & 56 & 83 & 56 & 83 & 56 & 83 \\
\hline Possibility to visit tourists from different places & 58 & 77 & 58 & 77 & 58 & 77 \\
\hline A Chance to Call and Exchange Cultural & 69 & 68 & 69 & 68 & 69 & 68 \\
\hline Visit the virgin and intact areas & 95 & 142 & 95 & 142 & 95 & 142 \\
\hline See the exciting landscapes of nature & 105 & 183 & 105 & 183 & 105 & 183 \\
\hline Earning fame and honor & 53 & 72 & 53 & 72 & 53 & 72 \\
\hline An opportunity for adventure & 58 & 99 & 58 & 99 & 58 & 99 \\
\hline Participate in sports & 56 & 81 & 56 & 81 & 56 & 81 \\
\hline Participation in birding competitions & 78 & 82 & 78 & 82 & 78 & 82 \\
\hline $\begin{array}{l}\text { Getting rid of overwhelming work and } \\
\text { reducing the stresses of urban living }\end{array}$ & 58 & 135 & 58 & 135 & 58 & 135 \\
\hline Escape from stress & 98 & 142 & 98 & 142 & 98 & 142 \\
\hline Vacation and away from busy environments & 93 & 141 & 93 & 141 & 93 & 141 \\
\hline
\end{tabular}


Data analysis through the LIKERT model: The motivations of tourists in the study district can be structured in three broad categories: high, mid and low motivations. According to the surveyors from the Dreka area, the most motivations for tourists were enjoyment of natural areas (83.13\%), recreation and leisure activities (79.36\%, observation of nature's exciting landscapes (79.35\%), privacy selection and avoidance of crowded environments (72.31\%), escape from daily routine (72.18\%), gathering together, visiting and traveling with friends and relatives (67.72\%), visiting pristine and untouched natural areas (62.67\%), and urban stress relief (60\%). Studies show that the least incentives in this area were recorded in activities such as buying and selling goods (37.43\%), visiting cultural and artistic attractions (41.77\%), and buying local souvenirs (43.78\%), and other activities (such as visits to historic monuments, familiarity with the culture of local residents, visits to various tourists, participation in competitions, the use of local cuisine, etc.) are at a moderate level of tourist incentives. On this basis, the nature, the basis of tourism incentives, and trade, are the least incentive for people in the Darakeh neighborhood.

This was also studied in Velenjak area. The results showed that the most motivations for tourism were enjoyment of natural areas $(81.35 \%)$, recreation and leisure (81.32\%), observing nature's exciting landscapes (78.20\%), getting rid of unpleasant work and urban life stresses (70.74\%), escaping from the routine (70\%), and attending birding (17 / 61\%), and the least incentives were related to activities such as buying and selling goods and business (35.2\%), buying local souvenirs (43.17\%). Accordingly, the assumption of broad participation in the reduction of conflicts between visitors' activities, which is one of the important analyzes and evaluations in the formation of integrated environmental management and the promotion of tourism sustainability and the health of the urban community in the District 1 of Tehran metropolis, is confirmed.

Table 3. The extent of tourists' participation in the development of tourism

in the region of a Tehran metropolis (special to Darakeh and Velenjak) using the LYKERT model

\begin{tabular}{|l|c|c|c|c|c|c|c|c|c|c|c|c|c|}
\hline \multirow{2}{*}{ Subject } & \multicolumn{4}{c|}{$\begin{array}{c}\text { Tourist Participation } \\
\text { in the Velenjak }\end{array}$} & \multicolumn{4}{c|}{$\begin{array}{c}\text { Tourist Participation } \\
\text { in the Darakeh }\end{array}$} \\
\hline & none & V L & L & M & H & V H & none & V L & L & M & H & $V H$ \\
\hline Nature conservation & 32 & 16 & 22 & 40 & 30 & 46 & 68 & 26 & 38 & 48 & 64 & 88 \\
\hline Protecting plant species & 30 & 22 & 22 & 26 & 50 & 28 & 62 & 18 & 34 & 86 & 116 & 62 \\
\hline Protect bird and animal species and damage & 52 & 24 & 20 & 14 & 36 & 22 & 68 & 22 & 46 & 84 & 65 & 63 \\
\hline Planting seedlings in the area & 78 & 22 & 24 & 22 & 16 & 10 & 170 & 12 & 60 & 68 & 28 & 16 \\
\hline Feeding domestic animals and birds & 62 & 24 & 26 & 8 & 28 & 16 & 112 & 26 & 52 & 94 & 26 & 30 \\
\hline $\begin{array}{l}\text { Preservation of Historical, Bastat and } \\
\text { Cultural Monuments }\end{array}$ & 24 & 8 & 28 & 46 & 43 & 26 & 61 & 29 & 38 & 89 & 36 & 45 \\
\hline Shooting, filming or painting of nature & 28 & 12 & 18 & 36 & 42 & 32 & 36 & 23 & 50 & 48 & 56 & 81 \\
\hline Clean the water resources of the area & 26 & 24 & 26 & 8 & 52 & 47 & 34 & 25 & 27 & 69 & 48 & 97 \\
\hline Keep nature clean & 26 & 9 & 26 & 25 & 49 & 58 & 53 & 32 & 38 & 85 & 28 & 83 \\
\hline Respect for people and local culture & 19 & 21 & 13 & 26 & 45 & 58 & 30 & 25 & 42 & 59 & 56 & 98 \\
\hline Compliance with the rules and regulations & 18 & 22 & 19 & 25 & 48 & 44 & 31 & 22 & 39 & 58 & 71 & 92 \\
\hline Nature conservation & 28 & 23 & 29 & 41 & 32 & 28 & 84 & 22 & 30 & 82 & 21 & 49 \\
\hline
\end{tabular}

Analyzing the extent of tourists' participation through the LIKERT model: Based on the evaluations, the rate of tourists' participation in the protection of Darakeh area was $56.57 \%$, conservation of plant species $59.15 \%$, protection of animal species and birds $54.08 \%$, planting of seedlings in the region $83 / 29 \%$, feeding of domestic animals and birds with $21 / 39 \%$, preservation of historical, archaeological and cultural heritage of 73/49\%, shooting, filming or painting of nature and species of the region, 95/60\%, cleanup of rivers and water resources of the region $64.2 \%$, keeping nature clean, $55.8 \%$, respecting people and local 
culture by $64.22 \%$, compliance with moral principles $65.1 \%$, and supporting the works of art Ray, souvenirs and local handicrafts (for example, their purchase) are also 63.65 percent. On the basis of this, it can be admitted that the highest participation of tourists in the Darakeh area was due to respect for the people and local culture, respect for local laws and regulations, and photography, filming and painting of the nature, while the lowest level of participation in activities such as planting and feeding on domestic animals and birds are recorded. Also, the results show that the rate of tourists' participation in Velenkak neighborhood in the protection of nature is equal to $56.95 \%$, protection of plant species $54.38 \%$, protection of animal species and birds $42.46 \%$, planting of seedlings in the region 07 / 29\%, feeding of domestic animals and birds $35.61 \%$, preservation of historical, ancient and cultural monuments $57.6 \%$, shooting, filming or painting of nature and species of the region, $62.67 \%$, clean water for rivers and water resources 34 / 59\%, nature conservation $64.45 \%$, respect for local life and traditional culture $0.66 \%$, adherence to moral principles $62.16 \%$, and souvenirs and local handicrafts are also 15/52 percent. In Velenjak area, the highest participation rate of tourists was in activities such as nature conservation, respect for people and local culture, and adherence to ethical principles, while the lowest level of participation in activities such as planting seedlings in the region, feeding domestic animals and birds, and the protection of animals and birds in the area and have not been harmed by them. Therefore, the assumption of a broad participation in urban environmental health, which is one of the important analyzes and evaluations in the formation of integrated environmental management and the promotion of tourism sustainability and the health of the urban community in the area of a Tehran city, is confirmed. In sum, the results of the inquiries indicate the participation rate of $74.73 \%$ of tourists in the Darakeh and $53.02 \%$ in the Velenjak areas.

Information infrastructure through the LYKERT model: With surveys conducted in the Darakeh area, it was found that the level of satisfaction of tourists with access to telecommunication networks was $40.48 \%$, Internet access 46. Percentages, access to bankers, 39.08 percent, access to newspapers with a massive rate of 43.04 percent, access to information centers by 47.52 percent, antithetical radio and television stations 41.2 percent, and mobile phone antithetic status $53 / 48$ percentages. The statistics indicate that the level of satisfaction of tourists from the information infrastructure in this area is low and that communication facilities need to be strengthened. This was also studied in the Velenjak area. The survey showed that the satisfaction of tourists from access to telecommunication networks was $45.52 \%$, internet access was $47.86 \%$, access to bankers was $43.03 \%$ Roster is the most widely advertised newspaper, 46.6\%, access to information centers, $49.58 \%$, the antithetical status of radio and television $48.5 \%$, and the mobile phone antidote status is $48.08 \%$. In the Velenjak area, the satisfaction of tourists from the information infrastructure is at a low level and it is necessary to plan appropriately in this regard. However, both assumptions of increasing participation in reducing conflicts between visitors' activities and urban environmental health in the formation of integrated environmental management and promotion of tourism sustainability within the boundaries of Tehran metropolitan have been approved.

\section{CONCLUSIONS AND SUGGESTIONS}

Today, the environmental crises in cities and the issues such as air pollution, water, soil, water scarcity and the use of non-renewable land, global warming and climate change, etc., has caused these problems become social issues. However, in recent years, growing concern for protection of the environment has caused that urban tourism become one of the main issue that is being discussed around the world. An increasing participation in the reduction of conflicts between visitors' activities and the improvement of environment is one of the important analyzes and evaluations in the formation of integrated 
environmental management, the promotion of tourism's sustainability and the health of the urban community in the District 1 of Tehran. On the basis of this, it can be admitted that the highest participation of tourists in the Darakeh was due to respect for the local habitants and their traditional culture, respect for local laws and regulations, and photography, filming and painting of the nature, while the lowest level of participation was in activities such as planting in the region, and feeding on domestic animals and birds are recorded. Therefore, the assumption of a broad participation in urban environmental health, which is one of the important analyzes and evaluations in the formation of integrated environmental management and the promotion of tourism sustainability and the health of the urban community in the area of a Tehran metropolis, is confirmed. In sum, the results of the inquiries indicate the participation rate of $74.73 \%$ of tourists in the Darakeh area and $53.02 \%$ in the Velenjak area. However, both assumptions of participation in reducing conflicts between visitors' activities and urban environmental protection in the formation of integrated environmental management and promotion of tourism sustainability within the boundaries of Tehran have been proved. Therefore, the suggestions and strategies necessary to achieve the goals of this research are as follows:

* In order to plan for the restoration and rehabilitation of worn-out tissues, factors such as tight passages that make transport difficult, and the problems of municipal solid waste disposal and wastes, are among the problems that must be identified and appropriate solutions presented.

* The use of new energies including solar, tidal, and nuclear energy to replace fossil fuels and reduce pollution

* Low-cost housing policy by the government for low-income groups and preventing the phenomenon of marginalization around cities.

* Formulating sustainability criteria and strategies for the environment and providing solutions for their realization, and identifying and reviewing environmental laws and regulations in relation to tourism-affected cities.

* To study the environmental impacts of projects and estimate the cost of national environmental protection, including conservation costs, elimination of pollution and destruction and other related tourism-related costs.

\section{REFERENCES}

Abe, K., Higashia, K. \& Ishikawa, J. (2000). Eco- labelling, environmental and international trade, in: http://www.computer-services.e.u-tokyo.ac.jp/p/seido/output/Ishikawa/o11.pdf.

Anderson, K. \& Braun, B. (2009). Environment critical eyes in human geography, published by ash gate, England.

Anna, C. Lisa, R. \& Michelle, W. (2017). Indigenous peoples and tourism: the challenges and opportunities for sustainable tourism, Journal of sustainable tourism. vol. 24, no. 8_9, 1067_1079. http://dx.doi.org/10.108o/o9669582.2016.1206112.

Badrifar, M. (2015). Human Geography of Iran, Payame Noor University Press.

Berkes, F. (2012). Sacred ecology, (3rd ed.). New York: Routledge.

Bomanian, M. R., \& Mahmoudineghad, H. (2016). Basics of Planning and Development of Rural Tourism, Tehran: Hale Pub.

Cafaro, O. (2001). Thoreau, Leopold, and Carson: Toward an environmental virtue ethics, Environmental Ethics, 23(1),3-17.

Ernawi, I. S. (2009). kearifan lokal dalam perspektif penataan ruang, In Wikantiyoso, Respati. (2009). "Prosiding Kearifan Lokal dalam Perencanaan dan Perancangan Kota untuk mewujudkan Arsitektur Kota yang berkelanjutan”. Penerbit Grup Konservasi Arsitektur dan Kota, Universitas Merdeka. Malang. ISBN 979-979-9488-43-5.

Faghfur M., H. (2009). Ethical Ethics from the Viewpoint of Islam, Medical Ethics Quarterly, vol. 3, no. 8, pp. 44-11.

Fanni, Z., \& Rezazadeh, S. M. (2015). The Role of Urban Tourism in Economic Development with an Approach (Case Study: Kermanshah Metropolis), National Conference on Sustainable Tourism with a Sports, Health and Environment Tourism Approach. University of Ardebil Researcher.

Faraji Rad, A., \& Nasiri, S. J. (2010). Tourism Planning in Urban Tourism Development, Geographical Quarterly of the Land, 7 (25). 
Fennel, D. (2009). Tourism ethics. Bristol: Multilingual Matters Limited.

Florian, W., Ashraf, S. \& Velina, M. (2015). Sustainable urban qualities in the emerging city of Doha, Journal of Current Issues in Tourism: http://www.tandfonline.com/loi/rjou20.

Foroughi, M. A. (1998). The History of Philosophy in Europe, First Edition, AmirKabir Publishing House, Tehran.

Gee, C. (2000). Professional travel agency management, Englewood cliffs prentice hall. English. Bookmark: https://trove.nla.gov.au/version/46659852.

Geertz, C. (1973). The Interpretation of Cultures. New York: Basic Books, Inc., Publishers.

Hall, C. M. (2002). Tourism planning, policies, processes and relationships person Education limited, Edinburg gate: England.

Hall, C. M., \& Jenkins, J. M. (2015), Tourism Policy, translation by S. M. Arabi, D. Izadi, Bureau of Cultural Research, Tehran.

Jalalian, K., \& Pajouyan, J. (2009). The Effect of Green Taxes and Good Governance on the Environment in OECD Countries, Journal of Economic Sciences, 2(7), 25-9.

J Carlos, M., \& Benjamin, E. (2013). Characterization Of Ecotoutism Employment In A Developing World Destination. GeoJournal of Tourism and Geosites . Year VI, no. 1, vol. 11, May 2013, p. 54-65 . Article no. 11106-126.

Leitmann, J., Bartone, C. \& Bernstein, J. (2010). Environmental management and urban development: issues and option for third world cities, environment and urbanization, 4 (2). 131-140.

Lew, A. (2010). Time as a major barrier to sustainable development. Tourism Geographies, 12, $481-483$. doi:10.1080/14616688.2010.494924.

Liao, K., \& Chan. (2016). What is ecological wisdom and how does it relate to ecological knowledge? Landscape and Urban Planning, 155, 108-110.

Lohamman, L. (2008). Green orientalism, the ecologist, 12(6), 202-204.

Mies , M., \& Shiva, V. (2005). Ecofeminism, London: zed book.

Movahed, A. (2017). Urban Tourism, Ahvaz: Chamran University Press.

Nugraha, I. (2010). Ekowisata dan Pembangunan Berkelanjutan. Penerbit : Pustaka Pelajar, Yogyakarta.

Papoli Yazdi, M. H., \& Saghaei, M. (2015). Tourism, Nature and Concepts, Publication of the Party.

Poulantzas, N. R. (1975). Reality and Law, Vol. I, Translated by: Ali Almasi, National University Press.

Raskhi, S., Karimi, S., \& Mohammadi, S. (2015). Tourism Effects on the Environment: A Case Study for Selected Developing and Developed Countries. Journal of Tourism Planning and Development, vol. 5, Number 16.

Redclift, M. (2008). The meaning of sustainable development, Geofourm, 23(3), 395-403.

Ress, W. E. (2010). The ecology of sustainable development, The Ecologist, 20 (1), 18-23.

Rojeck, C. \& Urry, J. (2008). Transformation of travel and theory, Touring cultures, London.

Ruslan, B., Lorant, D., Sholpan, A., Aiman, Z., \& Alexandr, A. (2018). Impacts of Tourism Activitise On Economy Of Kazakhstan . GeoJournal of Tourism and Geosites . Year XI, vol. 22, no. 2, 2018, p.480488. DOI 10.30892/gtg.22217-304.

Smith, S. (1995). Tourism analysis, A handbook. Longman Group limited 2nd Edition 21.

Soltani, K. (2008). The Set of Issues and Methods of Environmental Planning, Urban and Regional Planning, Volume 2, Publications Center for Studies and Researches on Urban and Architecture of Iran, First Edition, Tehran.

Steiner, F. (2016). The application of ecological knowledge requires a pursuit of wisdom. Landscape and Urban Planning: 155, 108-110.

Tribe, J. (2009). Philosophical issues in tourism. Bristol: Channel View.

Tume, G. (2015). Cultural and Environmental Development, translated by M. Sharepour, Tehran: Center for Essential Researches.

Wikantiyoso, R. (2009). Prosiding Kearifan Lokal dalam Perencanaan dan Perancangan Kota untuk mewujudkan Arsitektur Kota yang.

Xiang, W. (2016). Ecophronesis: The ecological practical wisdom for and from ecological practice. Landscape and Urban Planning, 155, 53-60.

Xiang, W.N. (2013). Working with wicked problems in socio-ecological systems: Awareness, acceptance, and adaptation. Landscape and Urban Planning, 110(1), 1-4.

Xiang, W.N. (2014). Doing real and permanent good in landscape and urban planning: Ecological wisdom for urban sustainability. Landscape and Urban Planning, 121, 65-69.

Yang, B., \& Li, S. (2016). Design with Nature: Ian McHarg's ecological wisdom as actionable and practical knowledge. Landscape and Urban Planning, 155, 21-32.

***(2014). Taufiqurrohman. P., Implementasi Kebijakan Hutan Kemasyarakatan (Studi Kasus Hutan Kemasyarakatan di Dusun Kalibiru, Kulon Progo). Thesis of Post Graduate in Public Administration Magister Program, Universitas Gadjah Mada. Yogyakarta; in: etd.repository.ugm.ac.id.

*** (2016). Tehran City Planning and Study Center, Detailed Planning District 1.

*** (1992). UNCED. The earth summit, UNESCO- UNEP environmental education newsletter, xvII (2), 1-8.

*** (2007). World Bank. world development report 1993: investing in health.

*** (1995). World tourism organization. Concepts, definitions and classifications for tourism statistics Madrid. http://www.encarta.msn.com/thesaurus/leisure.html

Submitted:

11.06.2018
Revised:

14.10.2018
Accepted and published online 17.10.2018 